\title{
Peningkatan Prestasi Belajar Menyimak pada Pembelajaran Tematik Integratif Melalui Multimedia Interaktif pada Siswa Sekolah Dasar
}

\section{Fauzatul Ma'rufah Rohmanurmeta}

PGSD FKIP UNIPMA

fauzatul@,unipma.ac.id

\begin{tabular}{ll}
\hline Informasi artikel & \\
\hline Sejarah artikel: & \\
Diterima & I4-II-2017 \\
Revisi & I6-04-2018 \\
Dipublikasikan & Mei 2018 \\
& \\
\hline
\end{tabular}

\section{Kata kunci:}

Prestasi Belajar Menyimak

Pembelajaran Tematik Integratif,

Multimedia Interaktif

\section{Key word:}

Learning Achievement Achievement Integrative Thematic Learning Interactive Multimedia

\begin{abstract}
ABSTRAK
Tujuan dalam penelitian ini adalah mengetahui penerapan multimedia interaktif, peningkatan prestasi belajar, dan kelebihan multimedia interaktif. Penelitian ini menggunakan pendekatan deskriptif kualitatif. Subyek yang diteliti adalah siswa kelas I yang berjumlah 24 orang. Jenis penelitian yang digunakan adalah penelitian tindakan kelas (PTK) dengan teknik pengumpulan data melalui tes, observasi, dan dokumentasi. Teknik analisis data ini menggunakan analisis data dengan model interaktif, dan dalam analisis serta kegiatan pengumpulan data menggunakan 2 siklus yaitu siklus I dan siklus II. Hasil penelitian menunjukkan adanya peningkatan prestasi belajar menyimak menggunakan multimedia interaktif pada pembelajaran tematik integratif dengan ketentuan nilai $\geq 70$ sebanyak $80 \%$ siswa, kerjasama siswa dengan ketentuan $\geq 75$ sebanyak $80 \%$ dan motivasi siswa dengan ketentuan nilai $\geq 75$ sebanyak $80 \%$. Sehingga dapat dilihat kelebihan multimedia interaktif ini adalah membuat pembelajaran lebih menyenangkan, dapat meningkatkan prestasi menyimak pembelajaran tematik integratif, menumbuhkan potensi siswa, meningkatkan kerjasama siswa. Sedangkan kekurangannya adalah memerlukan waktu yang lama dalam persiapannya dan membutuhkan ketersediaan fasilitas.
\end{abstract}

Copyright (C) 2018 Universitas Ahmad Dahlan. All Right Reserved

\section{Pendahuluan}

Pembelajaran tematik integrative merupakan suatu pembelajaran terpadu yang mengintegrasikan berbagai mata pelajaran dalam satu tema. Pembelajaran tematik integratif diberlakukan bagi siswa Sekolah Dasar dalam kurikulum 2013. Harapan utama adanya pembelajaran tematik integratif adalah dapat meningkatkan aspek pengetahuan, sikap, dan keterampilan. Pembelajaran tematik integratif berdasarkan kurikulum saat ini berbazis terhadap perkembangan karakter dan keterampilan, namun pelaksanaan pembelajaran tematik integratif di Sekolah Dasar saat ini masih banyak yang bersifat monoton dengan 
menggunakan buku ajar saja. Ada beberapa permasalahan di dalam kelas karena penerapan pembelajaran tematik integratif belum optimal. Permasalahan tersebut yaitu, prestasi belajar menyimak siswa masih cenderung rendah atau di bawah KKM. Adapun nilai tersebut adalah 60, dimana KKM yang telah ditetapkan adalah 70 . Interaksi di dalam pembelajaran tematik cenderung masih kurang. Hal tersebut menjadikan perkembangan afektif dan psikomotor siswa menjadi rendah. Kurangnya motivasi belajar dalam mempelajari pembelajaran tematik integratif karena kurangnya inovasi dalam pembelajaran tematik integratif. Aktifitas pembelajaran tematik integratif di dalam kelas belum menggunakan media pembelajaran yang menarik, sehingga pembelajaran bersifat membosankan.

Penyebab timbulanya permasalahan di kelas terkait pembelajaran tematik integratif diantaranya dikarenakan, materi pembelajaran tematik integratif kurang melekat dalam pemahaman diri siswa. Hal itu dikarenakan siswa mempelajari pembelajaran tematik hanya berpedoman pada buku saja. Pembelajaran akan lebih bermakna apabila bahan ajar disajikan melalui multimedia interaktif. Aktifitas yang terbangun pada pembelajaran tematik integratif masih pasif disebabkan kurang adanya tampilan bahan ajar yang menarik sehingga siswa merasa jenuh dan bosan.

Penerapan multimedia interaktif dalam mata pelajaran tematik integratif adalah upaya untuk mengatasi permasalahan dalam pembelajaran tematik integratif, serta dapat membuat siswa untuk belajar secara bermakna, sehingga dapat meningkatkan prestasi belajar tematik integratif. Dengan penggunaan multimedia interaktif dinilai dapat meningkatkan prestasi belajar menyimak siswa pada pembelajaran tematik integratif. $\mathrm{Hal}$ tersebut dikarenakan dengan belajar secara bermakna, pemahaman siswa terhadap materi akan lebih optimal sehingga prestasi belajar siswa pun akan meningkat. Multimedia interaktif dianggap sejalan dengan tujuan kurikulum yang diharapkan dapat meningkatkan aspek psikomotorik siswa khususnya menyimak melalui proses belajar secara bermakna.

\section{Metode}

Penelitian ini menggunakan pendekatan Kualitatif melalui metode Penelitian Tindakan Kelas (PTK). Pendekatan kualitatif merupakan prosedur penelitian yang menghasilkan data deskriptif berupa kata-kata tertulis atau lisan dari orang-orang dan perilaku yang diamati. Jenis penelitian ini merupakan Penelitian Tindakan Kelas (Classrom Action Research) yaitu usaha peningkatan kemampuan siswa yang dilakukan melalui kerja kolaborasi antara kepala sekolah, guru kelas dan peneliti di lingkungan. Penelitian ini dimaksudkan untuk memberi informasi bagaimana tindakan yang tepat untuk meningkatkan prestasi belajar menyimak siswa melalui multimedia interaktif. Teknik pengumpulan data yang digunakan adaah tes, dokumentasi, dan wawancara. Teknik analisis data pada penelitian ini adalah analisis data kualitatif. Dalam jenis kegiatan analisis dan kegiatan pengumpulan data itu sendiri merupakan siklus dan interaktif. Teknik analisis data dilakukan dengan menggunakan teknik analisis data model interaktif. Dalam analisis ini telah dikemukakan tiga hal utama, yaitu reduksi data, penyajian data, dan penarikan kesimpulan atau verifikasi.

\section{Hasil dan pembahasan}

\section{a. Hasil Penelitian}

Hasil penelitian ini meliputi data awal siswa terkait prestasi belajar menyimak pembelajaran tematik integratif, data hasil penerapan siklus satu dan data hasil penerapan siklus dua yang berorintasi pada prestasi belajar menyimak pembelajaran tematik integratif siswa kelas $\mathrm{V}$, data motivasi siswa dan data kerjasama siswa.

I. Data Awal Siswa.

Dari hasil observasi data awal siswa dapat dijelaskan bahwa siswa yang mengalami ketuntasan belajar sebanyak 12 anak dari 20 anak (60\%). Penetapan ketuntasan belajar berdasarkan indikator keberhasilan, yaitu mencapai nilai 70,0 sebagai batas ketuntasan belajar minimum.

2. Data Siklus I

a. Observasi

Kegiatan observasi digunakan untuk memperoleh data motivasi dan kerjasama siswa dalam pelajaran.

Motivasi.

Penggunaan media pembelajaran untuk meningkatkan prestasi belajar menyimak siswa kelas V pada siklus I mendapatkan respons yang baik dari siswa. Pada saat pembelajaran, siswa cukup banyak yang termotivasi dalam pembelajaran.

Kerjasama.

Hasil observasi penggunaan multimedia interaktif untuk meningkatkan prestasi belajar menyimak siswa pada siklus I sudah berjalan dengan baik. Tiap 
kelompok berani maju kedepan dan memerankan drama hasil dari kegiatan menyimak dengan baik dan kompak secara bergantian dan kelompok lain mengomentari isi dari drama yang diperankan dengan baik dan antusias.

b. Wawancara

Peneliti melakukan wawancara pada semua siswa. Teknik dari pengumpulan data melalui wawancara ialah dengan angket kuesioner. Hal tersebut bertujuan untuk mengetahui aktivitas siswa dalam pembelajaran, apresiasi pembelajaran, interaksi dalam pembelajaran, dan pengembangan setelah menerima pembelajaran.

c. Tes

Terdapat prestasi belajar menyimak pembelajaran tematik integratif menggunakan multimedia interaktif untuk meningkatkan prestasi belajar menyimak. Hasil test tersebut ialah hasil secara individu.

Tabel I. Indikator keberhasilan tindakan pada siklus I adalah sebagai berikut.

\begin{tabular}{|l|l|l|}
\hline Apek & Ketercapaian & Indikator \\
\hline Test & $70 \%$ & $80 \% \geq 70$ \\
\hline Motivasi & $70 \%$ & $80 \% \geq 70$ \\
\hline Kerjasama & $70 \%$ & $80 \% \geq 70$ \\
\hline
\end{tabular}

Dari paparan tabel diatas, dapat dijelaskan bahwa kurang dari $80 \%$ prestasi belajar siswa meningkat dengan multimedia interaktif. Pencapaian hanya 70\% dari 10 siswa yaitu 7 siswa yang telah mencapai ketuntasan pembelajaran tematik integratif dan 3 siswa belum tuntas. Pada observasi motivasi belajar dan kerjasama, kurang dari $80 \%$ siswa dapat memperhatikan pelajaran dengan baik dan antusias dalam pembelajaran serta bekerjasama secara kompak untuk menampilkan peran di depan kelas.

\section{Data Siklus 2}

a. Observasi

Kegiatan observasi digunakan untuk memperoleh data motivasi dan kerjasama siswa dalam pelajaran.

Motivasi.

Penggunaan multimedia interaktif untuk meningkatkan prestasi belajar menyimak siswa kelas $\mathrm{V}$ pada siklus II mendapatkan respons yang sangat baik dari siswa. Pada saat pembelajaran, siswa cukup banyak yang termotivasi dalam pembelajaran. Kerjasama.
Hasil observasi penggunaan multimedia interaktif untuk meningkatkan prestasi belajar menyimak siswa kelas I pada siklus II berjalan dengan lebih baik. Pada saat pembelajaran, utamanya pada diskusi kelompok dan berpendapat mengenai isi peran kelompok lain, siswa dapat menyampaikan pendapat dengan lebih dari 3 kali dalam berdiskusi.

b. Wawancara

Peneliti melakukan wawancara pada semua siswa kelas I. Teknik dari pengumpulan data melalui wawancara ialah dengan angket kuesioner. Hal tersebut bertujuan untuk mengetahui aktivitas siswa dalam pembelajaran, apresiasi pembelajaran, interaksi dalam pembelajaran, dan pengembangan setelah menerima pembelajaran.

c. Tes.

Terdapat prestasi belajar menyimak pembelajaran tematik integratif menggunakan multimedia interaktif untuk meningkatkan prestasi belajar menyimak pembelajaran tematik integratif. Hasil test tersebut ialah hasil secara individu.

Tabel 2. Indikator keberhasilan tindakan pada siklus I adalah sebagai beriku.

\begin{tabular}{|l|l|l|}
\hline Apek & Ketercapaian & Indikator \\
\hline Test & $80 \%$ & $80 \% \geq 70$ \\
\hline Keaktifan & $85 \%$ & $80 \% \geq 70$ \\
\hline Keberanian & $90 \%$ & $80 \% \geq 70$ \\
\hline
\end{tabular}


Dari paparan tabel diatas, dapat dijelaskan bahwa sudah lebih atau sama dengan $80 \%$ prestasi belajar menyimak siswa meningkat menggunakan multimedia interaktif. Selain hasil tes yang mengalami peningkatan, kegiatan berdiskusi dan tukar pendapat juga mengalami peningkatan. Hal tersebut dibuktikan dari hasil observasi bahwa kegiatan di siklus II yaitu pada aspek motivasi dan kerjasama siswa mampu meningkat. Lebih dari $80 \%$ siswa juga telah antusias dan bersemangat serta kompak ketika pembelajaran berlangsung.

\section{b. Pembahasan}

Penggunaan multimedia interaktif untuk meningkatkan prestasi belajar menyimak siswa melalui tindakan atau siklus dapat dikatakan berhasil. Sebelum tindakan menggunakan multimedia interaktif, nilai rata-rata siswa masih tergolong dibawah standard minimum. Siswa yang memiliki nilai kurang baik masih cukup banyak. Dari data tersebut, perlulah diadakan perlakuan untuk meningkatkan prestasi belajar menyimak pembelajaran tematik integratif.

Penerapan siklus I yang sudah mulai berjalan memiliki peningkatan pada hasil test nya, dan kegiatan diskusi siswa. Namun hal tersebut masih kurang untuk mencapai target yang dibuat. Penyebab kurangnya keberhasilan pada siklus I mungkin dikarenakan kurang konsentrasi siswa dalam memainkan peran serta memahami isinya. Selain hal tersebut, guru mungkin kurang memotivasi belajar siswa sehingga perlulah diadakannya siklus II.

Dalam kegiatan penerapan siklus II, guru mengubah cara belajar siswa yakni dengan menambah gambar pada materi pembelajaran yang sedang berlangsung untuk mampu merangsang pemikiran yang baru sehingga siswa lebih fokus terhadap materi. Selain itu, guru juga memberikan reward bagi siswa yang mampu mengungkapkan pendapat dan aktif pada saat pembelajaran. Hal tersebut berhasil memotivasi siswa untuk mampu aktif dalam pembelajaran yang dilakukan dan meningkatkan kerjasama dalam diri siswa dalam berdiskusi.

Sebelum melaksanakan tindakan, tingkat ketercapaian prestasi belajar menyimak siswa dalam pembelajaran tematik integratif hanya $60 \%$. Namun setelah diadakannya tindakan di siklus I, tingkat pencapaian siswa meningkat $10 \%$ dan kemudian dilanjut kembali di siklus II yang mengalami peningkatan $20 \%$ dari pra tindakan. Ketercapaian hasil tersebut karena dorongan dari guru dan kemampuan siswa melatih kembali memainkan peran, memahami isi, dan membacakannya dengan baik dan benar.

Dari data diatas pula, tingkat motivasi dan kerjasama siswa dalam mengungkapkan pendapat juga mengalami peningkatan. Pencapaian motivasi siswa dari siklus I ke siklus II mengalami peningkatan sebanyak 10\%. Sedangkan pencapaian kerjasama siswa dari siklus I ke siklus II mengalami peningkatan sebanyak I4\%.

Setelah penerapan siklus I dan siklus II untuk meningkatkan prestasi belajar pembelajaran tematik integratif menggunakan multimedia interaktif, berikut ini dijelaskan mengenai kelebihan dan kekurangan dari media ini.

Kelebihan multimedia interktif

I. Membuat pembelajaran lebih menyenangkan

Pembelajaran menggunakan multimedia interaktif membuat siswa menjadi aktif karena dengan menggunakan multimedia interaktif, siswa dapat berperan aktif di dalam pembelajaran sehingga siswa menjadi lebih tertarik terhadap proses pembelajaran sehingga pembelajaran menjadi lebih menyenangkan. Hal tersebut terbukti pada meningkatnya nilai dari respon siswa dari sebelum tindakan hingga pada siklus II.

Pada siklus I hampir semua siswa berpendapat dan melakukan diskusi dengan baik dan berperan aktif dalam pembelajaran. Dalam penilaian prestasi belajar menunjukan hasil $70 \%$ dari siswa I0 siswa mencapai kriteria ketuntasan minimal 70 , dan menunjukan rata-rata motivasi belajar didalam kelas $75 \%$ dari I0 siswa, dan kerjasama menunjukan ratarata $75 \%$ dari 10 siswa bekerja sama dengan baik.

Pada siklus II, hampir semua siswa menunjukan peningkatan prestasi belajar menyimak yang sangat siknifikan yaitu. Dalam penilaian prestasi belajar menyimak menunjukan hasil $80 \%$ dari siswa I0 siswa mencapai kriteria ketuntasan minimal 70, dan menunjukan rata-rata motivasi belajar didalam kelas $85 \%$ dari I0 siswa, dan kerjasama menunjukan rata-rata $90 \%$ dari 10 siswa bekerja sama dengan baik.

2. Menumbuhkan bakat dan potensi siswa

Dengan multimedia interaktif ini akan menumbuhkan bakat dan potensi siswa dalam pembelajaran. Sehingga 
potensi siswa akan tergali karena terbiasa melatih keberanian siswa dalam mengungkapkan pendapat dan tampil di depan kelas.

3. Meningkatkan kerjasama antar siswa Multimedia interaktif ini jika diterapkan dalam pembelajaran sangat meningkatkan kerjasama antar siswa karena siswa dituntut untuk bekerja dalam kelompok, dan meningkatkan kekompakan siswa dalam kelompok serta melatih siswa untuk menghargai pendapat teman satu kelompok dan membuat siswa menjadi antusias dalam mengikuti pelajaran. Hal tersebut terbukti pada meningkatnya nilai dari kemampuan kerjasama siswa dari sebelum tindakan hingga pada siklus II.

\section{Simpulan}

Dari hasil penelitian yang telah dilaksanakan dapat disimpulkan sebagai berikut:

I. Penerapan multimedia interaktif untuk meningkatkan prestasi belajar menyimak siswa karena aktifitas siswa meyenangkan, menarik dan bermakna. Penggunaan multimedia ini dapat melatih keberanian siswa dalam mengungkapakan pendapatnya dan meningkatkan motivasi belajar siswa serta kerjasama siswa dalam berdiskusi. Interaksi siswa sangat tampak ketika proses mengomentari materi yang diperankan teman. Terlihat banyak siswa yang mampu memberikan kritik dan saran dari materi yang disampaikan dari kelompok lain. Penggunaan media ini juga mendapat apresiasi yang baik. Siswa merasa tertarik dengan penggunaan media dalam penyampaian materi dan siswa menantikan pembelajaran dengan mengunakan multimedia interaktif dalam bentuk yang lain.

2. Prestasi belajar menyimak pada pembelajaran tematik integratif dengan multimedia interaktif.

a. Motivasi siswa mencapai indikator pencapaian motivasi dengan ketentuan mendapatkan nilai $\geq 75$ sebanyak $80 \%$ siswa.

b. Keterampilan kerjasama mencapai indikator pencapaian aspek kerjasama dengan ketentuan mendapatkan nilai $\geq 75$ sebanyak $80 \%$ siswa. c. Hasil prestasi belajar menyimak mencapai ndikator pencapaian aspek ketuntasan dengan ketentuan mendapatkan nilai $\geq 75$ sebanyak $80 \%$ siswa.

\section{Persantunan}

Artikel ini disusun atas dorongan dan dukungan dari berbagai pihak. Ucapan terimakasih disampaikan kepada PGSD FKIP UNIPMA dan teman-teman sejawat. Ucapan terima kasih juga disampaikan kepada tim editorial Bahastra Pendidikan Bahasa dan Sastra Indonesia Universitas Ahmad Dahlan yang telah memberikan ruang untuk penerbitan artikel ini. Semoga artikel ini dapat memberikan kontribusi dalam pembelajaran terutama dalam kegiatan literasi kritis.

\section{Daftar Pustaka}

Alwi, Hasan. Dkk. 2005. Kamus Besar Bahasa Indonesia. Jakarta: Balai Pustaka.

Daryanto. (2010). Media Pembelajaran. Yogyakarta: Gava Media.

Kemendikbud. (2013). Pendekatan Scientific (Ilmiah) dalam Pembelajaran. Jakarta: Pusbang prodik.

Munir. (2008). Kurikulum Berbasis Teknologi Informasi dan Komunikasi.

Bandung: Alfabeta.

Prasasti, P. A. T. (2017, July). Empowering Science Process Skill and Critical Thinking Through Guided Inquiry in Science Learning. In Proceeding Internasional Seminar of Primary Education(Vol. I).

Rohmanurmeta, F. M. R. (2016). Peningkatan Motivasi Belajar IPA Melalui Metode Pembelajaran Quantum Teaching Bagi Siswa Kelas IV. Premiere Educandum: Jurnal Pendidikan Dasar dan Pembelajaran, 5(02).

Rusman, 2012. Model-Model Pembelajaran. Bandung : Seri manajemen Sekolah bermutu

Sanjaya, Wina. 2012. Strategi Pembelajaran Berorientasi Standar Proses Pendidikan. Jakarta: Kencana Prenada Media Grup

Sumadi Suryabrata. (2006). Psikologi Pendidikan. Jakarta: PT Raja Grafindo Persada 